\title{
Potential antioxidant and antiproliferative activities of a hot-water extract from the root of Tonh khidum
}

\author{
JIQIANG LIU, ZHENYA ZHANG, GUOQING XING, HONGHAI HU, NORIO SUGIURA and INTABON KEO
}

\author{
Graduate School of Life and Environmental Sciences, University of Tsukuba, Tsukuba 305-8572, Japan
}

Received September 29, 2009; Accepted December 4, 2009

DOI: $10.3892 /$ ol_00000068

\begin{abstract}
In this study, for the first time, the possible antioxidant and antiproliferative activities of a hot-water extract (TW100) from the root of Tonh khidum (Actinidia kolomikta Maxim) were examined in vitro. Total phenolic compound, 1,1-diphenyl2-picrylhydrazyl (DPPH) radical-scavenging activity and superoxide dismutase (SOD)-like activity assays were utilized to investigate its antioxidant activity. As a result, TW100 showed a strong antioxidant activity. The total phenolic content of TW100 was $143 \mu \mathrm{g}$ gallic acid equivalents/mg. The SOD-like activity of TW100 was 666,667 U/g extract, and the DPPH radicalscavenging activity was $129 \mu \mathrm{g} / \mathrm{ml}$ at $\mathrm{EC}_{50}$ which was one third of vitamin $\mathrm{E}(40 \mu \mathrm{g} / \mathrm{ml})$. The antiproliferative effects and ability of the extracts to induce apoptosis were studied in vitro using human cervical cancer ME-180 cells. Results showed that TW100 inhibited the proliferation of ME-180 cells in a dose- and time-dependent manner except at a low concentration $(10 \mu \mathrm{g} / \mathrm{ml})$ with an $\mathrm{EC}_{50}$ at 24,48 and $72 \mathrm{~h}$ of $36.28,30.55$ and $29.78 \mu \mathrm{g} / \mathrm{ml}$, respectively. TW100 also induced apoptosis as determined by a nuclear fragmentation assay and an analysis of flow cytometry. In conclusion, the hot-water extract from the root of Tonh khidum possesses potential antioxidant and antiproliferative activities.
\end{abstract}

\section{Introduction}

Tonh khidum (Laotian), or Actinidia kolomikta Maxim, is a species of deciduous dioecious woody vine of the genus Actinidia. Tonh khidum can be cultivated not only in Laos but also in temperate mixed forests of the Russian far east, Korea, Japan and China (eastern Asiatic region). It is used in traditional medicine for the treatment of diabetes and inflammation in Laos. Although the source of Tonh khidum is abundant and cheap as a medicinal plant, to the best of our knowledge, no systemic research exists on its chemical

Correspondence to: Dr J.Q. Liu, Graduate School of Life and Environmental Sciences, University of Tsukuba, Tsukuba 305-8572, Japan

E-mail: tjljq1977jp@yahoo.co.jp

Key words: Tonh khidum, antioxidant activity, antiproliferative effect, ME-180 cell line, apoptosis constituents and bioactivities. In particular, no investigation has been reported in the literature regarding the antioxidant and antiproliferative properties of Tonh khidum in vitro.

It is commonly accepted that under situations of oxidative stress, reactive oxygen species (ROS) such as superoxide $\left({ }^{\circ} \mathrm{O}_{2}^{-}, \cdot \mathrm{OOH}\right)$, hydroxyl $\left({ }^{\circ} \mathrm{OH}\right)$ and peroxyl ( $\left.\mathrm{ROO}^{\bullet}\right)$ radicals are generated. ROS play an important role in degenerative or pathological processes such as aging (1), cancer, coronary heart disease, Alzheimer's disease (2-4), neurodegenerative disorders, atherosclerosis, cataracts and inflammation (5). Generally, cells possess endogenous systems [superoxide dismutase (SOD), catalase and glutathione peroxide] and diet-derived antioxidants (vitamin $\mathrm{C}$ and $\mathrm{E}$ ) that prevent or limit ROS-induced tissue damage (6). Oxidative stress occurs during an imbalance between ROS and antioxidants. Excessive production of ROS may lead to oxidative damage in DNA, proteins and other macromolecules resulting in their accumulation with age $(7,8)$. Hence, dietary intake of antioxidants is necessary and important. The use of traditional medicine is widespread, and plants still present a large source of natural antioxidants that may serve as leads for the development of novel drugs. In order to explore novel natural antioxidants, some antioxidant and radical scavenging components have been extensively studied in various plants in the past 30 years, such as chinacoside in Echinaceae root (9), anthocyanin (10), phenolic compounds (11), water extracts of roasted Cassia tora (12) and whey proteins (13-15).

Cervical cancer is the third most common malignancy in women worldwide and a significant cause of mortality and morbidity in women in the developing world (16). Despite progress in early detection and treatment, survival rates have not shown a marked improvement in the last 10-20 years. The development of new anticancer drugs is a key issue for cancer chemotherapy due to the fact that cancer cells, which are resistant to current chemotherapy, are able to dominate the cell population and cause mortality (17). Furthermore, traditional or herbal medicine as alternative cancer therapy has attracted a great deal of attention recently due to its low toxicity and cost.

In light of the above traditional uses of Tonh khidum and the current trend to develop antioxidants and anticancer drugs, we investigated the antioxidant activity and antiproliferative effect of Tonh khidum by assessing its ability to scavenge free radicals and inhibit the growth of human cervical cancer ME-180 cells in vitro. 


\section{Materials and methods}

Plant material. The dried roots of Tonh khidum were purchased from Laos. The dried roots were then ground in a mill, and the powder, with a particle diameter of $<0.2 \mathrm{~mm}$ (80-mesh), was used in the extraction preparation.

Extraction of TW100. The powder of the roots $(50 \mathrm{~g})$ was extracted with $1,000 \mathrm{ml}$ of distilled water at $100^{\circ} \mathrm{C}$ for $2 \mathrm{~h}$. After repetitive operation once, the extract was then centrifuged at 5,000 rpm for $10 \mathrm{~min}$ and filtered through Whatman \#1 filter paper (Whatman Inc., Hillsboro, OR, USA). The filtrate was concentrated in an evaporator at $40^{\circ} \mathrm{C}$, freeze-dried to a powder as a crude hot-water extract (TW100) by a freeze dryer (Christ Alpha, Germany) and stored at $-20^{\circ} \mathrm{C}$.

Determination of the polysaccharide content. Polysaccharide content was quantified with a modified phenol-sulfuric acid method according to Dubois et al (18). The extract was precipitated with $87.5 \%$ ethanol at $4^{\circ} \mathrm{C}$ overnight and then centrifuged at 7,000 $\mathrm{x}$ g for $30 \mathrm{~min}$. The precipitate was washed twice with absolute ethanol and evaporated in a vacuum to remove residual ethanol. The precipitated polysaccharide was dissolved in distilled water and used for the polysaccharide analysis. The color reaction was initiated by mixing $1 \mathrm{ml}$ of polysaccharide solution with $0.5 \mathrm{ml}$ of $5 \%$ phenol solution and $2.5 \mathrm{ml}$ of concentrated sulfuric acid. The reaction mixture was kept in a $100^{\circ} \mathrm{C}$ water bath for $15 \mathrm{~min}$. After cooling to room temperature, the optical density (OD) of the mixture was determined at $490 \mathrm{~nm}$, and the polysaccharide content was calculated with D-glucose as the standard. The results were expressed as $\mu \mathrm{g}$ of glucose equivalent/mg of extract.

Determination of total phenolic content. The total phenolic content of the extract was estimated according to the FolinCiocalteu colorimetric method with some modifications (19). A sample $(0.5 \mathrm{ml})$ was mixed with $0.5 \mathrm{ml}$ of the FolinCiocalteu reagent (Sigma, St. Louis, MO, USA). After $3 \mathrm{~min}$, $0.5 \mathrm{ml} \mathrm{Na}_{2} \mathrm{CO}_{3}(20 \%)$ was added, and the mixture was made up to $5 \mathrm{ml}$ with distilled water. After being kept in the dark for $90 \mathrm{~min}$, the OD of the mixture was read at $725 \mathrm{~nm}$. The quantification was determined based on a standard curve of gallic acid (25-250 $\mu \mathrm{g} / \mathrm{ml})$ (Sigma). Results were expressed as $\mu \mathrm{g}$ of gallic acid equivalent (GAE) per mg of extract.

Determination of SOD-like activity. The levels of SOD-like activity in the extracts were measured using the SOD Assay Kit-WST according to the technical manual provided by Dojindo Molecular Technologies, Inc. This assay relies on WST-1 [2-(4-iodophenyl)-3-(4-nitrophenyl-5-(2,4-disulfophenyl)-2H-tetrazolium, monosodium salt], which produces a water-soluble formazan dye upon reduction with ${ }^{\circ} \mathrm{O}_{2}^{-}$, a reaction inhibited by SOD. Briefly, in a 96-well microplate, $20 \mu \mathrm{l}$ of sample solution (Sample well and Blank2 well) or double-distilled water (Blank1 and Blank3) was mixed with $200 \mu \mathrm{l}$ of WST working solution. For Blank2 and Blank3, $20 \mu \mathrm{l}$ of dilution buffer was added. Then, $20 \mu \mathrm{l}$ of enzyme working solution was added to each Sample well and Blank1 well. The plate was incubated at $37^{\circ} \mathrm{C}$ for $20 \mathrm{~min}$, and the OD was determined at $450 \mathrm{~nm}$ using a microplate reader (Bio-Rad Model 550, USA). SOD-like activity (inhibition rate, \%) was calculated using the equation:

SOD-like activity (inhibition rate, $\%)=\left(\mathrm{A}_{\text {Blank1 }}-\mathrm{A}_{\text {Blank3 }}\right)-\left(\mathrm{A}_{\text {Sample }}-\mathrm{A}_{\text {Blank } 2}\right)$ / $\left(\mathrm{A}_{\text {Blank1 }}-\mathrm{A}_{\text {Blank3 }}\right)$ x 100.

In this equation, $A_{\text {Blank } 1}, A_{\text {Blank2 }}, A_{\text {Blank3 }}$ and $A_{\text {Sample }}$ were the absorbances of Blank1, Blank2, Blank3 and Sample well, respectively. One unit of SOD activity was defined as the amount of enzyme having a 50\% inhibitory effect on WST-1.

Scavenging activity against the DPPH radical. The effect of the extracts on the DPPH radical was estimated according to the method of Nakajima et al (20). The OD was measured at $570 \mathrm{~nm}$ with a microplate reader. DPPH radical-scavenging activity was assessed using the equation:

DPPH radical-scavenging activity $(\%)=(1-\mathrm{A}$ sample $/$ A control $) \times 100$.

In this equation, A sample and A control were the absorbances of the sample (tested extract) and control, respectively.

In this study, the scavenging activity of the sample was expressed as the $50 \%$ effective concentration $\left(\mathrm{EC}_{50}\right)$, which represented the sample concentration $(\mu \mathrm{g} / \mathrm{ml})$ inhibiting $50 \%$ of the DPPH radical activity.

Cell line. Human cervical cancer cell line ME-180 was obtained from the Institute of Development, Aging and Cancer, Tohoku University. The cells were cultured in RPMI-1640 medium (Sigma) supplemented with $10 \%(\mathrm{v} / \mathrm{v})$ heat-inactivated fetal bovine serum and antibiotics (100 U/ml penicillin and $100 \mu \mathrm{g} /$ $\mathrm{ml}$ streptomycin) at $37^{\circ} \mathrm{C}$ in a humidified atmosphere of $5 \%$ (v/v) $\mathrm{CO}_{2}$ in air. The cells were passaged twice a week.

WST-8 assay. To evaluate the effect of the extracts on the proliferation and viability of human cervical cancer cell line ME-180, the WST-8 [2-(2-methoxy-4-nitrophenyl)3-(4-nitrophenyl)-5-(2,4-disulfophenyl)-2H-tetrazolium, monosodium salt] colorimetric assay was performed using the Cell Counting Kit-8 (Dojin East, Tokyo, Japan) according to the manufacturer's instructions. Cells $(5,000 /$ well) were seeded into 96 -well cell plates in $100 \mu \mathrm{l}$ of culture medium for $24 \mathrm{~h}$ prior to drug exposure and then treated with various final concentrations of extracts $(10,25,50,75$ and $100 \mu \mathrm{g} / \mathrm{ml})$ for various durations (24, 48 and $72 \mathrm{~h}$ ). Controls were treated with distilled water as the vehicle. After drug exposure for the indicated concentration and time, $10 \mu \mathrm{l}$ of WST- 8 reagent were added and incubated for $4 \mathrm{~h}$ at $37^{\circ} \mathrm{C}$. Cell viability was indicated by the OD at $450 \mathrm{~nm}$ with a microplate reader. Data were expressed as percentages of the control.

Nuclear fragmentation assay. Cells were seeded in 6-well plates at a density of $2 \times 10^{5}$ cells $/ \mathrm{ml}$ containing $2 \mathrm{ml}$ of the medium. The cells were cultured for $24 \mathrm{~h}$ and then treated with TW100 $(50 \mu \mathrm{g} / \mathrm{ml})$ or distilled water. After 24 or $48 \mathrm{~h}$ of incubation, the changes in the nuclei were observed using a Leica fluorescence microscope after staining with Hoechst $33258(200 \mu \mathrm{g} / \mathrm{ml})$. 


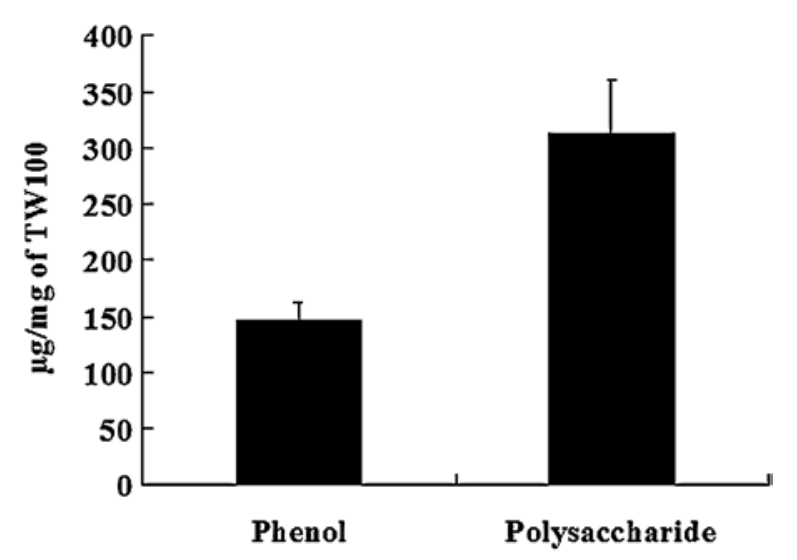

Figure 1. Polysaccharide and total phenolic content of TW100. Data are expressed as the mean $\pm \mathrm{SD}$ of three experiments.

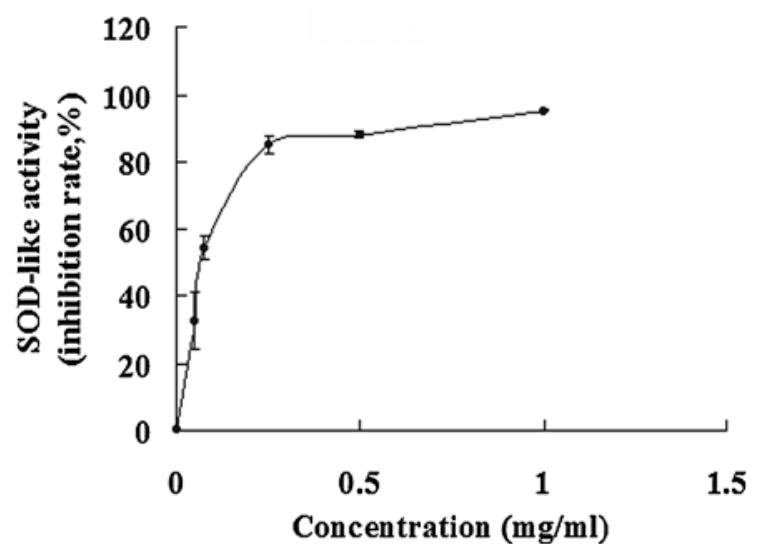

Figure 2. SOD-like activity of TW100. Data are expressed as the mean \pm SD of three experiments.

Detection of apoptosis by flow cytometry. Briefly, cells were seeded in 6-well plates at a density of $2 \times 10^{5}$ cells/ml and allowed to attach overnight, and then treated with the extract $(50 \mu \mathrm{g} / \mathrm{ml})$ or distilled water for 24 or $48 \mathrm{~h}$. The cells were harvested by trypsin treatment, washed twice with cold PBS, fixed in cold $70 \%$ ethanol for at least $4 \mathrm{~h}$ at $4{ }^{\circ} \mathrm{C}$, re-suspended in $3 \mathrm{ml}$ PBS for $5 \mathrm{~min}$, filtered with a 400 mesh sieve, stained with propidium iodide (PI) solution $(50 \mu \mathrm{g} / \mathrm{ml}$ of PI with $100 \mu \mathrm{g} / \mathrm{ml}$ of RNase in PBS) at $4^{\circ} \mathrm{C}$ for $30 \mathrm{~min}$ in the dark, and subjected to flow cytometry. The percentage of apoptotic cells was estimated using a flow cytometer (BD-LSR, BD Biosciences), and the data were obtained and analyzed with CellQuest software (Becton Dickinson).

Statistical analysis. Means of triplicates were measured. The Student's t-test was used for comparison between two treatments. A difference was considered to be statistically significant when $\mathrm{p}<0.05$.

\section{Results}

Extraction yield. There was a yield of $11.3 \mathrm{~g} / 100 \mathrm{~g}$ of Tonh khidum from TW100 on the basis of the experiment method used in this study.

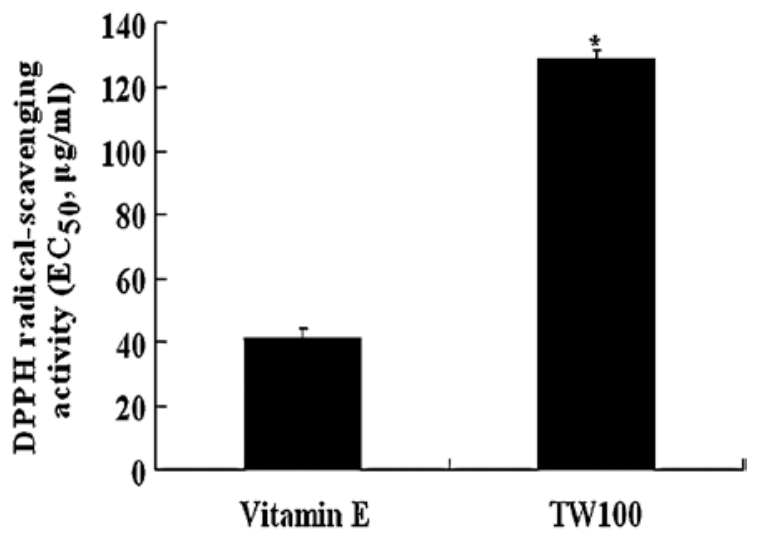

Figure 3. DPPH radical-scavenging activity of TW100 and vitamin E. Data are expressed as the mean $\pm \mathrm{SD}$ of three experiments ( ${ }^{*} \mathrm{p}<0.05$ vs. vitamin $\left.\mathrm{E}\right)$.

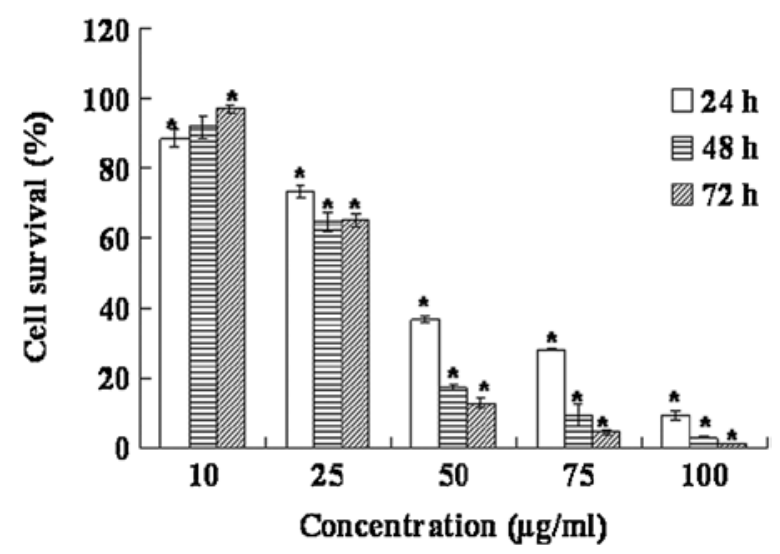

Figure 4. Antiproliferative effects of the various concentrations of TW100 on ME-180 cells. Viable cells were estimated by the WST- 8 assay, and cell viability was expressed as a percentage of the control. Data are expressed as the mean \pm SD of three experiments (" $\mathrm{p}<0.05 \mathrm{vs}$. control).

Polysaccharide and total phenolic content. As shown in Fig. 1, the polysaccharide content was $311.5 \mu \mathrm{g} / \mathrm{mg}$ extract for TW100, and the total phenolic content was $143 \mu \mathrm{g}$ GAEs/mg extract.

SOD-like activity. In this experiment, we investigated the SOD-like activity of TW100 with five different concentrations. As shown in Fig. 2, the SOD-like activity was close to $95 \%$ at $1 \mathrm{mg} / \mathrm{ml}$. Accordingly, one unit of SOD activity was defined as the amount of enzyme having a 50\% inhibitory effect on WST-1. Thus, we calculated the SOD activity of TW100 to be 666,667 U/g extract.

DPPH radical-scavenging activity. In order to investigate the DPPH radical-scavenging activity of TW100, we selected vitamin $\mathrm{E}$ with a strong DPPH radical-scavenging activity as a positive control. As shown in Fig. 3, the DPPH radicalscavenging activity of TW100 $\left(\mathrm{EC}_{50}, 129 \mu \mathrm{g} / \mathrm{ml}\right)$ was close to one third of vitamin $\mathrm{E}\left(\mathrm{EC}_{50}, 40 \mu \mathrm{g} / \mathrm{ml}\right)$. A lower $\mathrm{EC}_{50}$ value indicated a higher DPPH radical-scavenging activity in this experiment.

Antiproliferative effect. The antiproliferative activities of TW100 on the growth of the human cervical cancer ME-180 
A

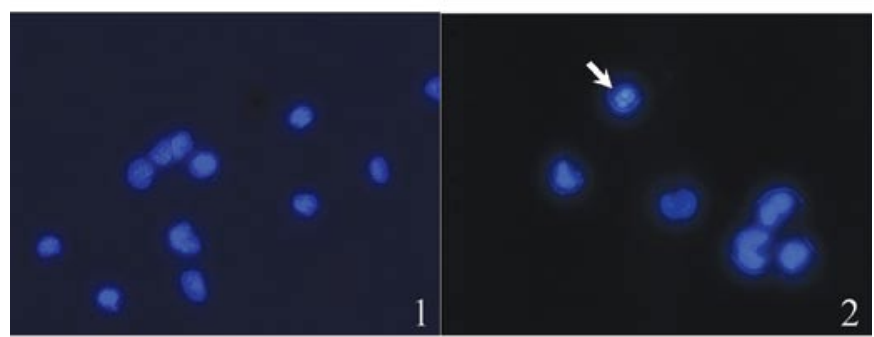

$\mathbf{B}$

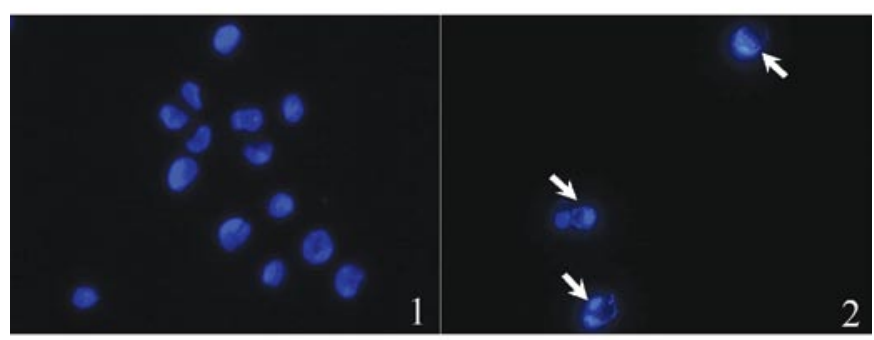

Figure 5. Nuclear morphology of ME-180 cells treated with TW100. Nuclear morphological changes were observed by fluorescence microscopy. ME-180 cells were incubated without extracts (A1 and B1) or with TW100 $(50 \mu \mathrm{g} / \mathrm{ml})$ (A2 and B2). A and B are the treatment durations of 24 and $48 \mathrm{~h}$, respectively. The arrows point to apoptotic cells. Magnification $\mathrm{x} 400$.

cell line in vitro are shown in Fig. 4. TW100 inhibited the proliferation of ME-180 cells in a dose- and time-dependent manner, except at a low concentration $(10 \mu \mathrm{g} / \mathrm{ml})$. The antiproliferative activities of $100 \mu \mathrm{g} / \mathrm{ml} \mathrm{TW100} \mathrm{were} \mathrm{as}$ high as $99 \%$ at $72 \mathrm{~h}$, and the $\mathrm{EC}_{50}$ of the antiproliferative activities of TW100 at 24, 48 and $72 \mathrm{~h}$ were $36.28,30.55$ and $29.78 \mu \mathrm{g} / \mathrm{ml}$, respectively. A lower $\mathrm{EC}_{50}$ value indicated higher antiproliferative activities in this experiment.

Apoptotic morphological changes. Exposure of ME-180 cells to TW100 $(50 \mu \mathrm{g} / \mathrm{ml})$ for 24 and $48 \mathrm{~h}$ induced clear morphological changes, such as nuclei fragmentation (Fig. 5A2 and $\mathrm{B} 2$ ), but the same phenomena were not observed for the control (Fig. 5A1 and B1) at 24 and $48 \mathrm{~h}$.

Percent change in apoptotic cells. The percentage of apoptotic cells reached 11.37 and $29.55 \%$ with TW100 $(50 \mu \mathrm{g} / \mathrm{ml})$ treatment at 24 and $48 \mathrm{~h}$, respectively. No significant differences were noted in the percentage of apoptotic cells in the control at any time point (Fig. 6).

\section{Discussion}

The current study demonstrated, for the first time, that the crude hot-water extract (TW100) of Tonh khidum showed a strong antioxidation activity, reduced viability and induced apoptosis in human cervical cancer ME-180 cells. These findings were achieved based on the SOD-like activity assay, DPPH scavenging activity assay, cell viability assay, morphological observations and FACS analysis.

Since antioxidant activities are closely linked to various diseases, aging and cancer, a growing number of people ingest natural herbal extracts with strong antioxidant activity for maintenance of their health. Natural antioxidants may also
A

B
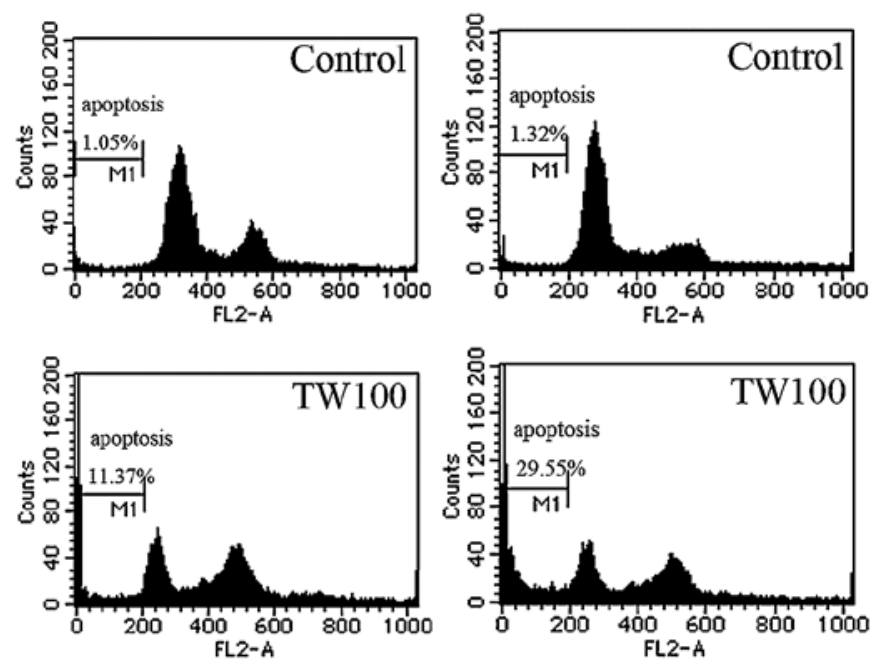

Figure 6. The percentage of apoptosis in M-180 cells treated with TW100. The percentages of apoptotic cells were obtained by flow cytometry. ME-180 cells were incubated without extracts (A and B - Control) or with $50 \mu \mathrm{g} / \mathrm{ml}$ TW100 (A and B - TW100). A and B are the treatment durations of 24 and $48 \mathrm{~h}$, respectively.

be associated with the pharmacological activities of plant and microbial sources. In this study, the potential antioxidant activity of TW100 was assessed based on two different assay techniques. It was confirmed by the stable radical (DPPH) scavenging effect $\left(\mathrm{EC}_{50}, 129 \mu \mathrm{g} / \mathrm{ml}\right)$ and strong SOD-like activity $(666,667 \mathrm{U} / \mathrm{g}$ extract). Since the induction of apoptosis is now considered to be an favorable strategy for cancer therapy $(21,22)$, we also investigated the antitumor activity $\left(\mathrm{EC}_{50}\right.$ at $48 \mathrm{~h}, 28.2 \mu \mathrm{g} / \mathrm{ml})$ and the induction of apoptosis $(11.37 \%$ at $24 \mathrm{~h}$ and $29.55 \%$ at $48 \mathrm{~h}$ ) of TW100. These activities of Tonh khidum provide a pharmacological background for its future use as an adjuvant or combination chemotherapy for the treatment of cancer.

Polysaccharides are being extensively explored for their potential use in the treatment and prevention of cancer. The bioactivity of polysaccharides in traditional medicine, particularly from medical plants, has been investigated for many years (23-27). Some polysaccharides have the ability to scavenge free radicals, induce differentiation of cancer cells and enhance animal or human antitumor ability via the activation of various immune responses in the host (24,27-29). We also confirmed that TW100 had a high polysaccharide content (311.5 $\mu \mathrm{g} / \mathrm{mg}$ extract). In order to further confirm whether or not the active components of TW100 are polysaccharides, we plan to purify polysaccharides in TW100 and evaluate their antioxidant and antitumor activities in future studies.

Dietary antioxidants can induce cell differentiation as well as inhibit proliferation and apoptosis depending on the dose and type of antioxidant, treatment schedule and tumor cell type without producing similar effects in most normal cells in vitro and in vivo $(30,31)$. However, whether there is a relationship between the antioxidant and anticancer activity is a controversial issue at present. We observed that TW100 showed not only strong antioxidation, but also 
strong anticancer activities. To prove whether there is a specific relationship, we analyzed the relevance between the various antioxidation and anticancer activities using Excel. We found that the phenolic content was significantly correlated with anticancer activity $\left(r^{2}=0.93, p<0.05\right)$, but both DPPH radical-scavenging and SOD-like activity showed no relationship with antiproliferative activity. On the other hand, the phenolic content was significantly correlated with DPPH radical-scavenging and SOD-like activity $\left(r^{2}=0.94, p<0.05\right.$ and $r^{2}=0.99, p<0.05$, respectively). These results suggest that the inhibition of tumor cell proliferation in vitro by TW100 is unable to be explained solely by the concentration of phenolic compounds or antioxidation. Thus, the inhibition of cancer cell proliferation is also attributed to some unknown compound(s) present in the hot-water extracts of Tonh khidum. Other phytochemicals may play a significant role in the antiproliferative activity of Tonh khidum. In subsequent investigations, the active component(s), which may be novel antitumor component(s), will be isolated from Tonh khidum.

To the best of our knowledge, no published results of a similar investigation exist. This study may, for the first time, confirm that the crude hot-water extract of Tonh khidum exhibits potent antioxidant and antitumor activities. However, the active components of Tonh khidum have yet to be elucidated. Thus, further studies are needed to investigate the relationship between these active components and the pharmacological efficacy of Tonh khidum.

\section{Acknowledgements}

We thank the Institute of Development, Aging and Cancer, Tohoku University for donated the ME-180 cells. We are also very grateful for access to FACS at the Department of Comprehensive Human Science of the University of Tsukuba.

\section{References}

1. Burns J, Gardner PT, Matthews D, Duthie GG, Lean ME and Crozier A: Extraction of phenolics and changes in antioxidant activity of red wine during vinification. J Agric Food Chem 49: 5797-5808, 2001.

2. Ames BN: Dietary carcinogens and anticarcinogens: oxygen radicals and degenerative disease. Science 221: 1256-1264, 1983.

3. Gey KF: The antioxidant hypothesis of cardiovascular disease: epidemiology and mechanisms. Biochem Soc Trans 18: 1041-1045, 1990.

4. Diaz MN, Frei B, Vita JA and Keaney JF: Antioxidants and atherosclerotic heart disease. N Engl J Med 337: 408-416, 1997.

5. Aruoma OI: Free radicals, oxidative stress and antioxidants in human health and disease. J Am Oil Chem Soc 75: 199-212, 1998.

6. Buechter DD: Free radicals and oxygen toxicity. Pharmaceut Res 5: 253-260, 1988.

7. Fraga CG, Shigenaga MK, Park JW, Degan P and Ames BN: Oxidative damage to DNA during aging: 8-hydroxy-2'-deoxyguanosine in rat organ DNA and urine. Proc Natl Acad Sci USA 87: 4533-4537, 1990 .

8. Harman D: The aging process. Proc Natl Acad Sci USA 78: 7124-7128, 1981.

9. $\mathrm{Hu} \mathrm{C}$ and Kitts DD: Studies on the antioxidant activity of Echinacea root extract. J Agric Food Chem 48: 1466-1472, 2000 .
10. Espin JC, Soler-Rivas C, Wichers HJ and Viguera-Garcia C: Anthocyanin-based natural colorants: a new source of antiradical activity for foodstuff. J Agric Food Chem 48: 1588-1592, 2000.

11. Rice-Evans CA, Miller NJ and Paganga G: Antioxidant properties of phenolic compounds. Trends Plant Sci 2: 152-159, 1997.

12. Yen GC and Chuang DY: Antioxidant properties of water extracts from Cassia tora $\mathrm{L}$. in relation to the degree of roasting. J Agric Food Chem 48: 2760-2765, 2000.

13. Allen JC and Wrieden WL: Influence of milk proteins on lipid oxidation in aqueous emulsion. I. Casein, whey protein and R-lactalbumin. J Dairy Res 49: 239-248, 1982.

14. Allen JC and Wrieden WL: Influence of milk proteins on lipid oxidation in aqueous emulsion II. Lactoperoxidase, lactoferrin, superoxide dismutase and xanthine oxidase. J Dairy Res 49: 249-263, 1982.

15. Tong LM, Sasaki S, McClements DJ and Decker EA: Mechanisms of the antioxidant activity of a high molecular weight fraction of whey. J Agric Food Chem 48: 1473-1478, 2000.

16. Parkin DM, Pisani P and Ferlay J: Estimates of the worldwide incidence of 25 major cancers in 1990. Int J Cancer 80: 827-841, 1999.

17. Kang SA, Park HJ, Kim MJ, Lee SY, Han SW and Leem KH: Citri Reticulatae Viride Pericarpium extract induced apoptosis in SNU-C4, human colon cancer cells. J Ethnopharmacol 97: 231-235, 2005.

18. Dubois M, Gilles KA, Hamilton JK, Rebers PA and Smith F: Colorimetric method for determination of sugars and related substances. Anal Chem 28: 350-356, 1956.

19. Singleton VL and Rossi JA: Colorimetry of total phenolics with phosphomolybdic-phosphotungstic acid reagents. Am J Enol Vitic 16: 144-158, 1965.

20. Nakajima Y, Sato Y and Konishi T: Antioxidant small phenolic ingredients in Inonotus obliquus (persoon) Pilat (Chaga). Chem Pharm Bull 55: 1222-1226, 2007.

21. Thompson CB: Apoptosis in the pathogenesis and treatment of disease. Science 267: 1456-1462, 1995.

22. Smets LA: Programmed cell death (apoptosis) and response to anti-cancer drugs. Anticancer Drugs 5: 3-9, 1994.

23. Fujimiya Y, Suzuki Y, Oshiman K, et al: Selective tumoricidal effect of soluble proteoglucan extracted from the basidiomycete, Agaricus blazei Murill, mediated via natural killer cell activation and apoptosis. Cancer Immunol Immunother 46: 147-159, 1998.

24. Kodama N, Komuta K, Sakai N and Nanba H: Effects of D-Fraction, a polysaccharide from Grifola frondosa on tumor growth involve activation of NK cells. Biol Pharm Bull 25: 1647-1650, 2002.

25. Liu M, Li J, Kong F, Lin J and Gao Y: Induction of immunomodulating cytokines by a new polysaccharide-peptide complex from culture mycelia of Lentinus edodes. Immunopharmacology 40: 187-198, 1998.

26. Liu F, Ooi VEC and Fung MC: Analysis of immunomodulating cytokine mRNAs in the mouse induced by mushroom polysaccharides. Life Sci 64: 1005-1011, 1999.

27. Wang YY, Khoo KH, Chen ST, Lin CC, Wong CH and Lin CH: Studies on the immuno-modulating and antitumor activities of Ganoderma lucidum (Reishi) polysaccharides: functional and proteomic analyses of a fucose-containing glycoprotein fraction responsible for the activities. Bioorg Med Chem 10: 1057-1062, 2002.

28. Chen YY and Chang HM: Antiproliferative and differentiating effects of polysaccharide fraction from fu-ling (Poria cocos) on human leukemic U937 and HL-60 cells. Food Chem Toxicol 42: 759-769, 2004.

29. Sun C, Wang JW, Fang L, Gao XD and Tan RX: Free radical scavenging and antioxidant activities of EPS2, an exopolysaccharide produced by a marine filamentous fungus Keissleriella sp. YS 4108. Life Sci 75: 1063-1073, 2004.

30. Prasad KN, Cole WC, Kumar B and Prasad KC: Scientific rationale for using high-dose multiple micronutrients as an adjunct to standard and experimental cancer therapies. J Am Coll Nutr 20: 450-463, 2001.

31. Prasad KN, Cole WC, Kumar B and Prasad KC: Pros and cons of antioxidant use during radiation therapy. Cancer Treat Rev 28: 79-91, 2002. 